\title{
Immune Cells Depletion During Wound Healing as a Long- Term Effect of Undernutrition
}

\author{
Depleción de Células Inmunocitarias Durante la Curación de una Herida \\ como Efecto de Desnutrición Postnatal
} "Marcelo Zuanassi Macari; "Fabiano Misael Cavenaghi; "Marilena Chinali Komesu; "Laurelúcia Orive Lunardi; "Miguel Angel
Sala; ${ }^{* *}$ Arthur Belém Novaes Júnior; ** Márcio Fernando de Moraes Grisi; ***ário Taba Júnior \& ** Sérgio Luiz Scombatti de Souza.

MACARI, M. Z.; CAVENAGHI, F. M.; KOMESU, M. C.; LUNARDI, L. O.; SALA, M. A.; NOVAES JÚNIOR, A. B.; GRISI, M. F. M.; TABA JÚNIOR, M. \& SOUZA, S. L. S. Immune cells depletion during wound healing as a long-term effect of undernutrition. Int. J. Morphol., 23(1):25-32, 2005.

SUMMARY: Undernutrition in early life is associated with a number of acute and chronic sequelae, and recovering is a controversial issue. Even if undernutrition in Brazil is declining, studies have shown that about $31 \%$ of brazilian children still present severe or moderate malnutrition. The present study goal was to induce early malnutrition in rats and observe short- (undernourished) and long-term (after recovered) effects on defense cells involved in wound healing. Undernutrition was produced by separating the pups from the mother for 10 hours/day during the suckling period (21 days after birth). As controls were used rats at same age not submitted to suckling restriction. Undernutrition and recovering states were assessed by body weight. Skin wounds were made on the shaved backs of all, undernourished, recovered and their controls, under tribromoethanol anesthesia. Aninals were sacrificed 1, 3, 7 and 14 days after surgery and the tissues were properly prepared and observed under light microscopy. Our results showed that: 1) neutrophils, lymphocytes and macrophages couting in healing area were lower in undernourished and in recovered animals as compared with their controls; 2) there were a basal deficiency in lymphocytes and macrophages numbers in recovered animals but not in those acutelly undernourished. These results allow us to conclude that post-nattally undernourished animals submitted to a nutritional rescue time showed a complete recovery in physical weight, but in spite of the physical recovery, the wound healing showed less defense cell density in healing areas suggesting long-term sequelae of early undernutrition.

KEY WORDS: Undernourishment; Wound healing; Defense cells.

\section{INTRODUCTION}

Healing is associated with a considerable increase of protein synthesis rate. Clinical reports have found poor wound healing in malnourished patients, and experimental studies indicated that wound healing is impaired after prolonged dietary restriction. Clinical studies consider a weight loss of $10 \%$ as a significant evidence of undernutrition (Emery \& Sanderson, 1995; Ayello et al., 1999).

Malnutrition is still a problem in the Brazil, and studies have pointed out that $31 \%$ of younger children (up to 5 year old) may present moderate or severe undernutrition (Reichenhein \& Hasselmann, 1977). Early malnourished children presented anatomical, neurological, neurochemical and hehavioral alterations, some of them persisting even after recovery from undernutrition. Malnourished children also presented lymphoid tissues atrophy and their cell-mediated immunity is significantly altered (Chandra, 1991; Keller et al., 1992; Manjarrez et al., 1996)

The wound healing process is divided into three phases: i) an initial inflammatory phase; ii) a proliferative phase; and iii) a remodeling phase. The inflammatory phase is characterized by infiltration of neutrophils, which are rapidly replaced by mononuclear cells. The proliferative phase is characterized by the presence of mononuclear inflammatory cells, followed by the formation of granulation tissue, and the proliferation of fibroblasts and keratinocytes.

\footnotetext{
* Department of Morphology, Stomatology and Physiology, Ribeirão Preto, School of Dentistry - University of São Paulo, Brazil

**a Department of Oral Surgery, Ribeirão Preto, School of Dentistry, University of São Paulo, Brazil.
} 
The final remodeling phase is that of maturation of the neoformed tissue (Moore et al., 1997).

Malnutrition, caused by a low protein-calorie diet may significantly alter the processes of tissue regeneration, inflammatory reaction, and immune functions, and studies have demonstrated that deffects during the inflammatory phase of wound healing may impair subsequent fibroblast growth and collagen synthesis (Goodson III \& Hunt, 1979). Considering these facts, the present research was designed to observe the effects of undernutrition on inflammatory cells during wound healing, particularly after recovering from the undernutritional state.

\section{MATERIAL AND METHOD}

Two main groups $(\mathrm{n}=30)$ of Wistar rats were prepared as follows: Group I-undernourished animals; Group IIundernourished/recovered. Post-natal undernutritrition of the experimental animals was promoted by separating the pups from their mothers daily for 10 hours, along the whole suckling period ( 21 days after birth). After 21 days, half of the undernourished animals were then normally fed until recovery (Group II). Control groups $(n=30)$ were of the same age as experimental animals, but they were not submitted to suckling restriction. Undernourished and recovered states were assessed by body weight measurements, following the procedure of Barret \& Frank (1987). Recovered animals were considered those achieving at least $90 \%$ of the mean control body weight.

After the period of undernutrition (21 days), and recovery (3 months), all the animals were submitted to the following surgical procedures. Under tribromoethanol (Aldrich, $25 \mathrm{mg} / 100 \mathrm{~g}$ body weight) the back of all the rats (control and undernourished groups) were shaved and skin wounds ( $4 \mathrm{~mm}$ diameter), each side of the median line, were prepared, separated around $2 \mathrm{~cm}$ from each other (Fig. 1) as a modification of Mustoe et al. (1987); Whitby and Ferguson (1991); and Most et al. (1996). Povidone-iodine was used as antiseptic, and all the animals received an association of penicilin (12.000 U/Kg of body weight) + streptomycin $(5 \mathrm{mg} / \mathrm{Kg})$ in one dose of Pentabiotico Veterinario (Fort Dodge â) just after surgery. (Fig. 1).

Five animals were sacrificed after 1 hour, 6 hours, 1 day, and 3 days after surgery (for neutrophils evaluation) and $1,3,7$, and 14 days after surgery (for lymphocytes and macrophages evaluation). The specimens were submenrsed in 10\% formalin solution for 24 hours or in Carnoy for 4 hours, and then embedded in paraffin. $6 \mathrm{~mm}$ thickness sections stained in hematoxilin and eosin (HE), or Giemsa were examined under a light microscope. Wound healing area was observed in details.

For cell counting, neutrophils and lymphocytes were observed in HE stainned tissues, and macrophages in Giemsa stained tissues (Gaffney, 1983). An immage analyser program (KS-300, version 2.0) for cell counting and comparison among groups were utilized. 10 randomly selected wound healing areas $\left(182618 \mu \mathrm{m}^{2}\right)$ were evaluated for each animal. By selecting a specific pattern of counting the KS-300 program determines the number of cells existing in a specific selected area. The total number of each selected cell type present in the healing area was counted. A Mann-Whitney's U-test was used for the statistical analysis. P[U] values $\leq$ 0.05 were considered as statistically significant.

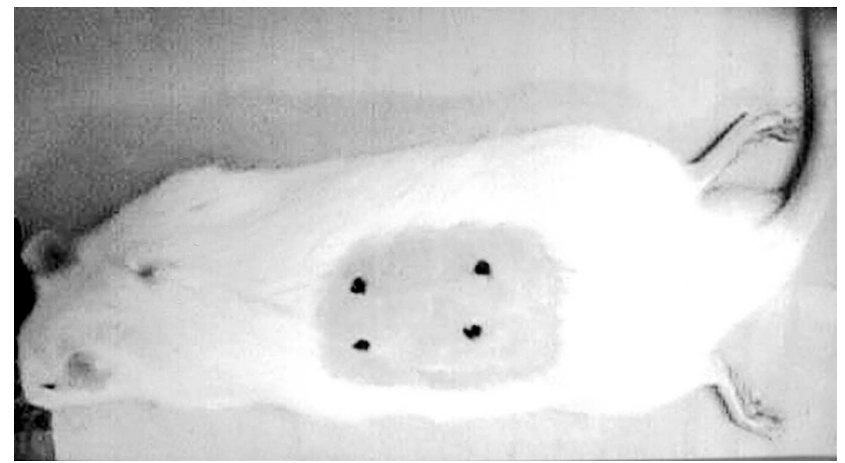

Fig. 1. Example of the surgery procedure in the rat.

\section{RESULTS}

Nutritional state evaluation. In all the animals body weight was evaluated every 2 days during the undernutrition period, and every 7 days during the recovery period (Table I). The results indicate that undernourished animals had body weights significantly reduced (61-75\% of the control group) and were recovered after 3 months in normal food.

Considering our initial hypothesis, we utilize the undernourishment classification created by Barret \& Frank for a known population. This classification defines in normal untritional state those with at least $90 \%$ of the expected body weight; under light undernutition those with $76 \%-89 \%$; with moderate undernutrition those between $61 \%$ to $75 \%$; and under severe undernutrition the animals with $\leq 60 \%$ of the expected body weight. According to this, the undernourished animals that had $72 \%$ of the expected body weight after 21 days of suckling restriction, were considered to be under a moderate undernutritional state. After 3 months of recovery, the undernourished animals showed a mean body weight of at least $90 \%$ of the control animals (Table I). 


\begin{tabular}{lccc} 
& Control & Undernourished & \% of control \\
\hline $1^{\text {st }}$ day (experimental period) & 5.79 & 5.92 & - \\
Acute Undernourishment & 48.10 & 34.64 & $72.0 \%$ \\
$1^{\text {st }}$ Month recovering & 57.26 & 41.77 & $73.0 \%$ \\
$2^{\text {nd }}$ Month recovering & 167.95 & 134.78 & $80.3 \%$ \\
$3^{\text {rd }}$ Month recovering & 289.25 & 262.81 & $90.9 \%$
\end{tabular}

\begin{tabular}{lcccc}
\hline & \multicolumn{2}{c}{ Undernourished } & \multicolumn{2}{c}{ Undernourished/Recovered } \\
& Control & Undernourished & Control & Uunder/Rec. \\
Day 1 after surgery & $0.0 \%$ & $0.0 \%$ & $0.0 \%$ & $0.0 \%$ \\
Day 3 after surgery & $14.5 \%$ & $10.0 \%$ & $11.96 \%$ & $6.4 \%$ \\
Day 7 after recovery & $35.7 \%$ & $35.5 \%$ & $33.8 \%$ & $36.4 \%$ \\
Day 14 after recovery & $55.4 \%$ & $51.5 \%$ & $51.6 \%$ & $52.3 \%$ \\
\hline
\end{tabular}
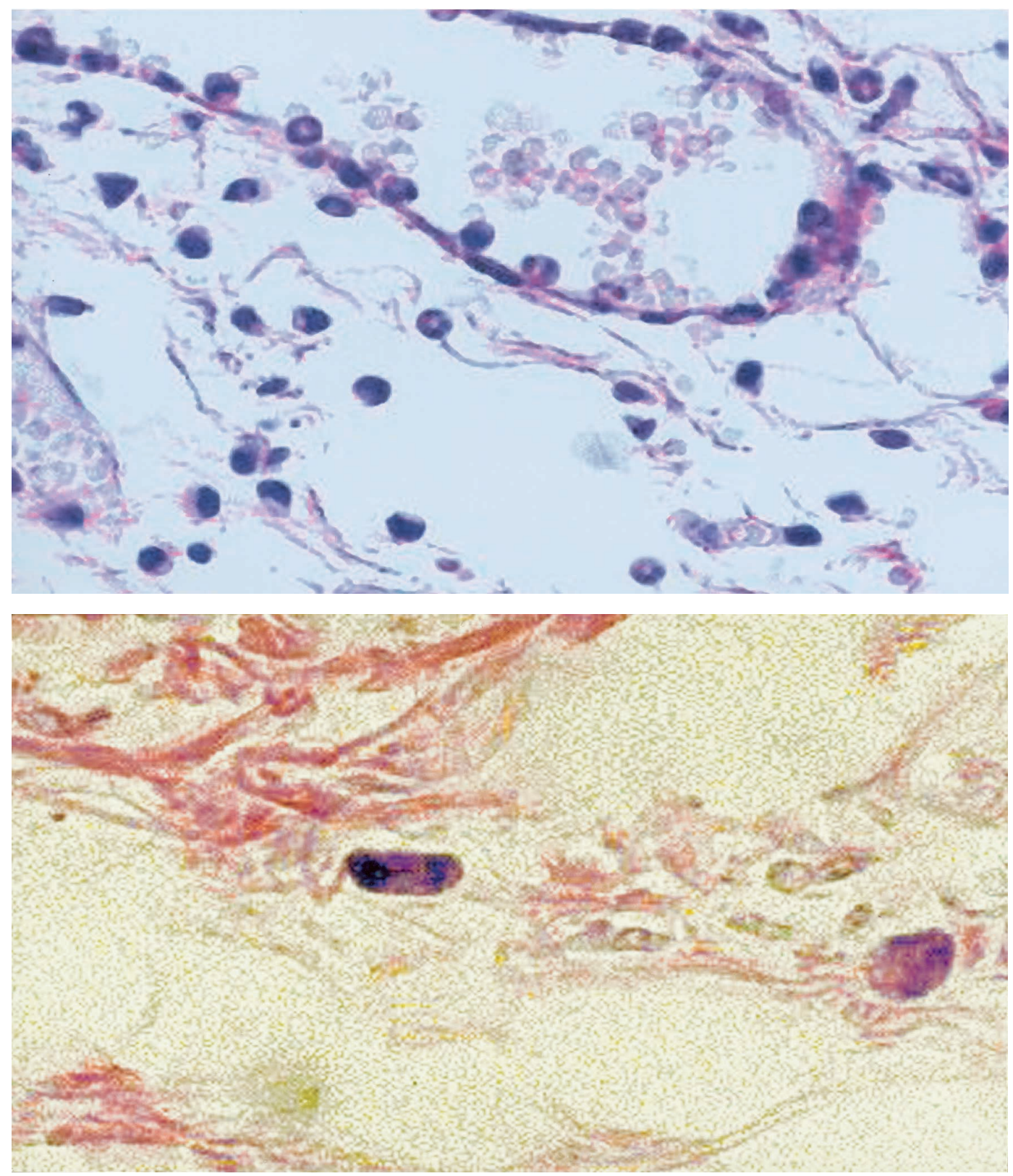

Wound healing velocity: The wound healing velocity was measured by the epithelial neoformation, counting the percent of points on the new epithelium on the healing area. The results of this evaluation is present on Table II.

Cell counting: In all the animals (undernourished (UND) and their controls (C), and undernourished/recovered (U/R) and their controls (C/R), neutrophils, lymphocytes and macrophages were counted. Figs. 2 and 3 shows examples of the used images.
Fig. 2. Healing area. HE stained for neutrophils and lymphocytes counting. $225 \mathrm{x}$.
Fig. 3. Healing area. Giemsa stained for Macrophages counting. $225 \mathrm{x}$. 
Figs. 4 to 6 show the results of cells counting in all the studied animals. Tables 3 to 5 summarizes the results of cells counting on the healing areas, at different times after skin surgery.

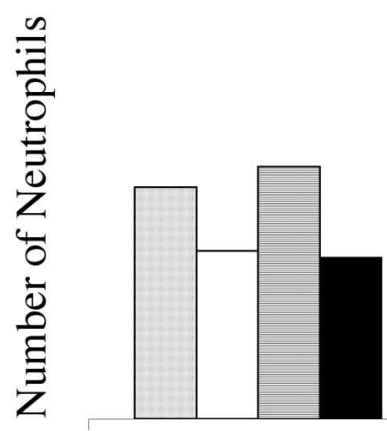

Day 1

Neutrophils counting

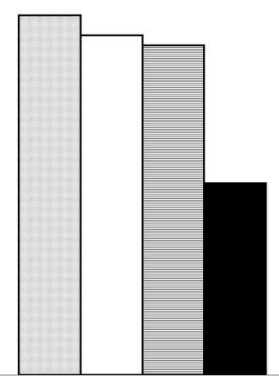

Day 3

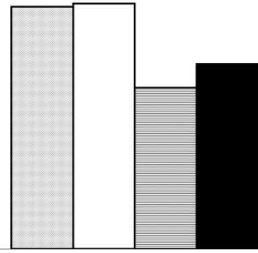

Day 7 $\square \mathrm{C}$

$\square$ UND

$\square \mathrm{C} / \mathrm{R}$

$\square \mathrm{U} / \mathrm{R}$

Time after surgery

Fig. 4. Neutrophils counting in the studied animals. Data in numbers are presented on Table II.

\section{Lymphocytes counting}

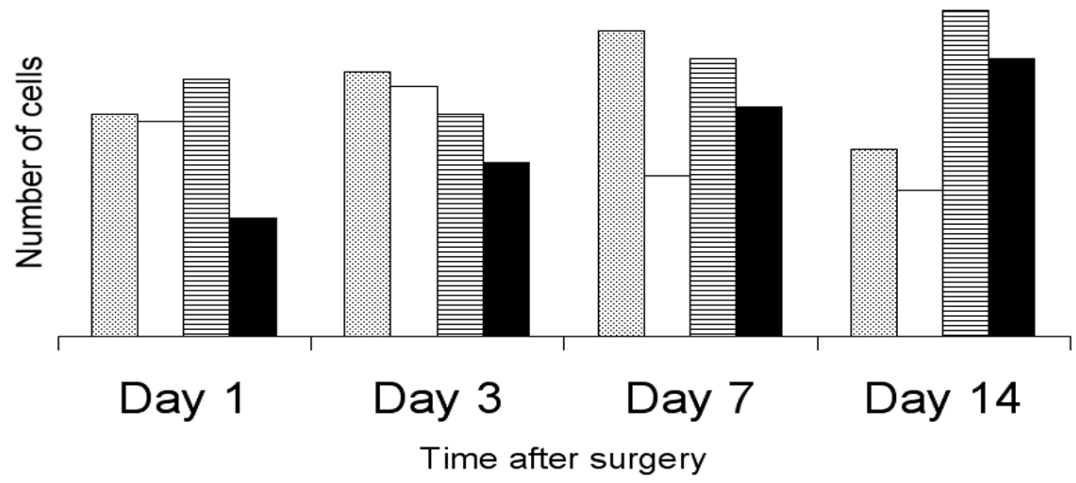

Fig. 5. Lymphocytes counting in the treated animals (Und, U/R) and their controls (C, C/R), respectively.

Macrophages counting

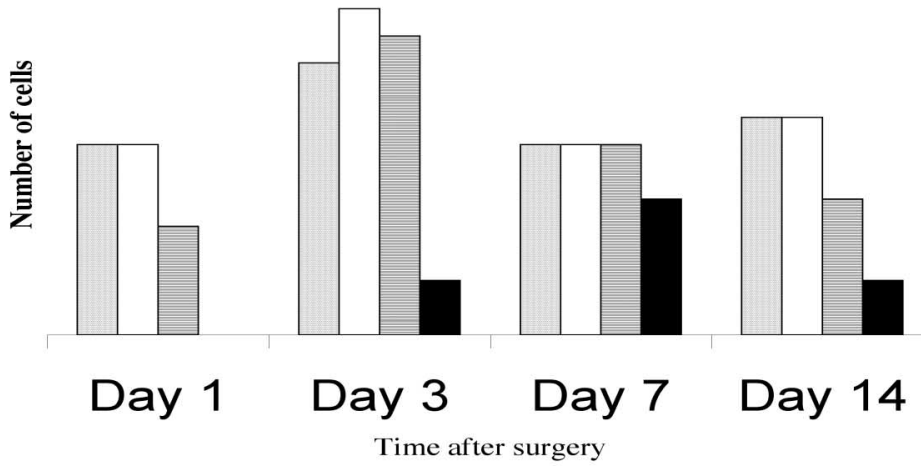

Fig. 6. Macrophages counting in the in the treated animals (Und, U/R) and their controls $(C, C / R)$, respectively. 


\begin{tabular}{|c|c|c|c|c|c|c|c|c|c|c|c|c|c|c|c|}
\hline \multicolumn{8}{|c|}{ UNDERNOURISHED } & \multicolumn{8}{|c|}{ UNDERN./RECOVERED } \\
\hline \multicolumn{2}{|c|}{1 hour } & \multicolumn{2}{|c|}{6 hour } & \multicolumn{2}{|c|}{1 day } & \multicolumn{2}{|c|}{3 days } & \multicolumn{2}{|c|}{1 hour } & \multicolumn{2}{|c|}{6 hour } & \multicolumn{2}{|c|}{1 day } & \multicolumn{2}{|c|}{3 days } \\
\hline $\mathrm{C}$ & Und & $\mathrm{C}$ & Und & $\mathbf{C}$ & Und & $\mathrm{C}$ & Und & $\mathrm{C} / \mathrm{R}$ & $\mathbf{U} / \mathbf{R}$ & $\mathrm{C} / \mathrm{R}$ & $\mathbf{U} / \mathbf{R}$ & $\mathrm{C} / \mathrm{R}$ & $\mathbf{U} / \mathbf{R}$ & $\mathbf{C} / \mathbf{R}$ & UR \\
\hline 20 & 45 & 158 & 108 & 124 & 245 & 151 & 93 & 25 & 56 & 160 & 70 & 156 & 96 & 105 & 81 \\
\hline 20 & 33 & 146 & 97 & 210 & 112 & 89 & 89 & 20 & 36 & 120 & 91 & 92 & 129 & 76 & 56 \\
\hline 78 & 59 & 168 & 114 & 237 & 207 & 52 & 98 & 58 & 24 & 135 & 74 & 89 & 67 & 73 & 98 \\
\hline 69 & 78 & 134 & 120 & 192 & 143 & 73 & 121 & 53 & 41 & 152 & 73 & 192 & 130 & 148 & 62 \\
\hline 45 & 63 & 192 & 153 & 114 & 156 & 172 & 106 & 45 & 25 & 120 & 96 & 96 & 119 & 88 & 128 \\
\hline 46 & 56 & 160 & 118 & 175 & 172 & 107 & 101 & 40 & 36 & 137 & 81 & 125 & 108 & 98 & 85 \\
\hline \multicolumn{2}{|c|}{$\begin{array}{l}\text { Difference } \\
\text { from control }\end{array}$} & $26 \%$ & $\downarrow$ & & & & & & & $41 \%$ & $\downarrow$ & & & & \\
\hline
\end{tabular}

\begin{tabular}{llllllll}
\hline \multicolumn{7}{c}{ Mann Whitney's U-Test } \\
\hline Calc. $\mathrm{U}=10$ & Calc. $U=2$ & Calc. $\mathrm{U}=12$ & Calc. $\mathrm{U}=10$ & Calc. $\mathrm{U}=10$ & Calc. $U=O$ & Calc. $\mathrm{U}=11$ & Calc. $\mathrm{U}=9$ \\
$\mathrm{P}[\mathrm{U}]=0.345$ & $P[U]=0.016$ & $\mathrm{P}[\mathrm{U}]=0.500$ & $\mathrm{P}[\mathrm{U}]=0.345$ & $\mathrm{P}[\mathrm{U}]=0.345$ & $P[U]=0.004$ & $\mathrm{P}[\mathrm{U}]=0.421$ & $\mathrm{P}[\mathrm{U}]=0.274$ \\
\hline
\end{tabular}

Table III. Counting of neutrophils in healing areas of rat skin at 1 hour, 6 hours, 1 day and 3 days after surgery. Treatments were: C: Control for undernourished; Und: Undernourished; C/R: Control for undernourished/recovered, and U/R: Undernourished/Recovered animals. The results of the Mann Whitney's U-Test for mean comparison are presented below (P[U] 0.500 indicate significant values).

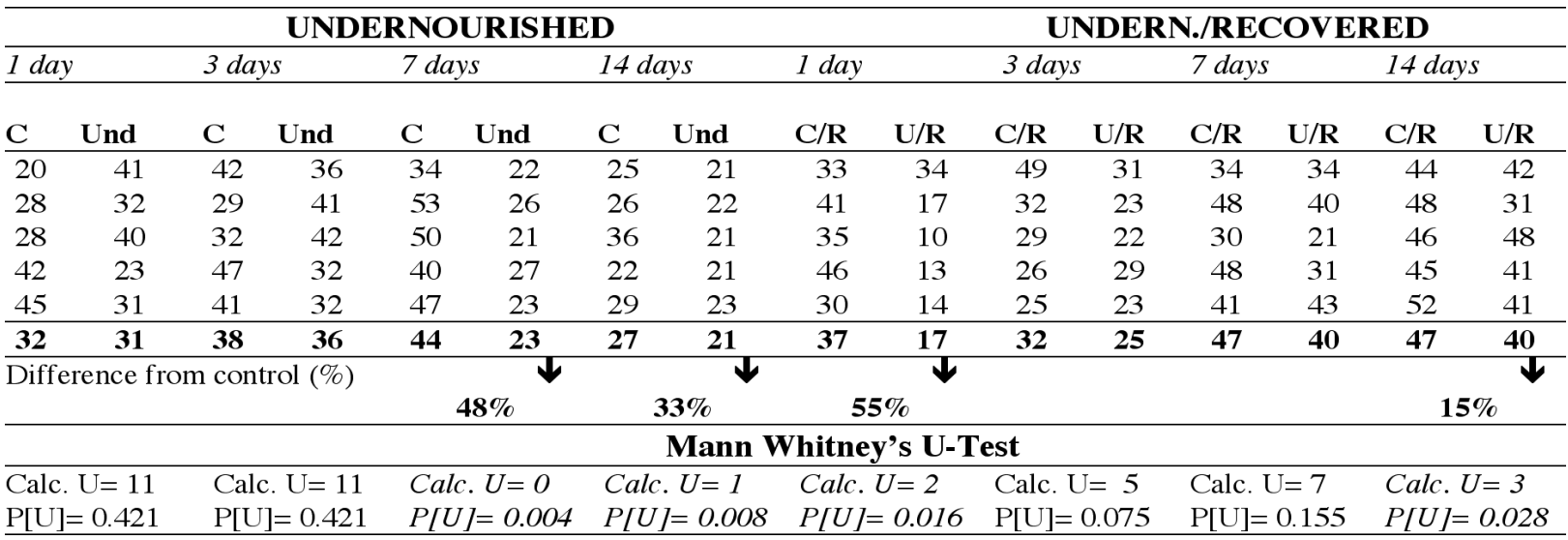

Table IV.Counting of lymphocytes in healing areas of rat skin at 1, 3, 7 and 14 days after surgery. Treatments were C: Control for undernourished; Und: Undernourished; C/R:Control for Undernourished/Recovered, and U/R: Undernourished/Recovered animals. The results of the Mann Whitney's U-Test for mean comparison are presented below (P[U] $\leq .500$ indicate significant values).

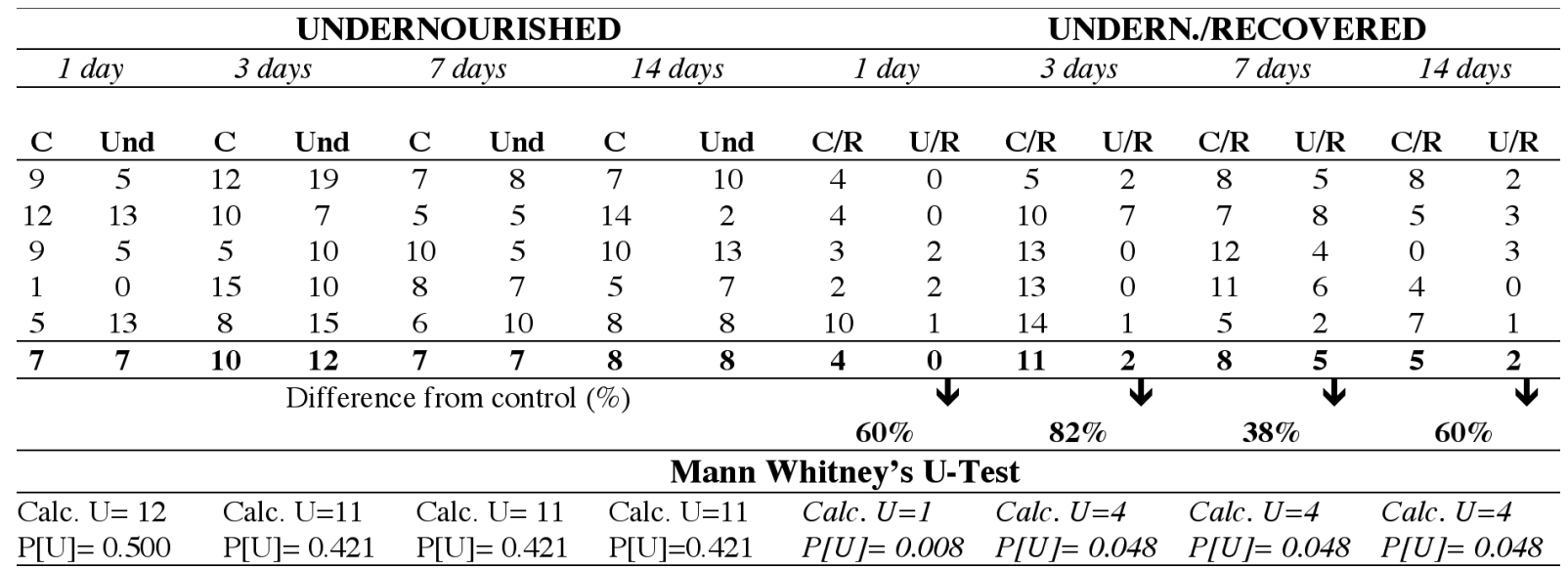

Table V. Counting of macrophages in healing areas of rat skin at 1, 3, 7 and 14 days after surgery. Treatments were C: Control for undernourished; Und: Undernourished; C/R: Control for Undernourished/Recovered, and U/R: Undernourished/Recovered animals. The results of the Mann Whitney's U-Test for mean comparison are presented below (P[U] 0.500 indicate significant values). 
The obtained data showed that: Neutrophils counting indicated a significant reduction of cell number during the initial inflammatory stage of wound healing, for all the undernourished animals. This reduction became even larger in recovered animals.

As expected, undernourished animals showed a small density of lymphocytes 7 days after surgery. However, lymphocytes counting also revealed a basal deficiency in lymphocytes from the very first day after surgery in recovered animals.

Counting of activated macrophages also showed a basal deficiency of these cells in healing wounded skin areas of recovered animals.

\section{DISCUSSION}

Tissue repair process occurs in an ordered sequence of events, beginning with an inflammatory response of the wounded area (that lasts about 3 days), followed by the formation of granulation tissue ( 3 to 7 days after lesion); then the accumulation of new connective tissue ( 7 to 14 days after lesion) and finally the remodeling phase (which may take some months to be completed). The inflammatory response and the formation of new connective and epithelial tissue could be observed in the studied animals.

Some interesting studies (Tarlton et al., 1997; Loots et al., 1998; Salmon-Ehr et al., 2000) concluded that the inflammatory response is a necessary and important stage of wound healing, and it is also assumed that an abnormal inflammatory response may have profound effects on the resolution of the repair process. Iinhibition of the repair process might also promote wound infection.

Some studies about the influence of undernutrition on wound healing may show different results, probably due to the use of different grades or types. In most of the experimental studies, stronger influences of undernourishment on wound healing are expected, because of the severe nutrient depletion involved in it. However, epidemiological studies have revealed that protein-calorie malnutrition is a widespread problem among infants and young children of developing countries, and in poverty areas of the industrialized nations. Severe forms of malnutrition can be easily detected, but milder degrees of malnutrition can be misinterpreted. However, a moderate degree of undernutrition is more common among children, generally associated with negligence and carelessness from the parents (Reichnhein \& Hasselmann). In this study we applied a moderate degree of undernutrition as the pattern, in order to observe the long-term effect of this very common type of undernutrition.

There are several methods for causing experimental undernutrition (Shakir, 1979). Our results allowed us to identify a moderate state of undernutrition in an animal population. After achieving post-natal undernutrition, the malnourished animals were submitted to nutritional rescue, showing recovery of physical growth (at least $90 \%$ of the body weight of controls) after a 3-month recovery.

It is generally accepted that individuals have variable cellular predisposition to respond to injury. While the reasons for this variability are not completely understood, it can be partially explained by the "background" or the "gene expressions". Nevertheless, the mechanisms of failure of the wound healing process are still unknown.

Wound healing is a complex process involving multiple cellular and extracellular components, all of them necessarily present in a normal healing process.

Inflammatory cells, fibroblasts and keratinocytes are very important types of cells that during the healing process modulate the reconstruction of the injured area. Inhibition of inflammatory cell infiltration and activation might also reduce the expression of growth factors in the wounded area, as demonstrated in experimental studies with glucocorticoids (Punch \& Ivinski, 1977). There are also indications that undernutrition at early life stages produces lymphoid tissue atrophy (Frank et al., 1996). Therefore, the results obtained in this study provide further support for the hypothesis that cellular deficiencies are associated with impaired wound healing. This subject deserves further research.

In spite of the general agreement existing about the complicated approach of extrapolating animal results to humans, our results for acutely undernourished animals were in concordance with those cited in the literature, either for humans or animals, and do not contest the already available knowledge about undernutrition. Consequently, our results also support the hypothesis that early malnutrition has late effects on the wound healing process, even after physical recovery. The results obtained here provide support for the hypothesis that early moderate malnutrition can be associated with deficiencies in the defense cells involved in wound healing, which may be associated with some wound healing deficiencies during the adult life, even after recovering from undernutrition.

ACKNOWLEDGEMENTS: This study was partially supported by the CNPq (300773/98-6) fund, and FAPESP (98/04721-2). 
MACARI, M. Z.; CAVENAGHI, F. M.; KOMESU, M. C.; LUNARDI, L. O.; SALA, M. A.; NOVAES JÚNIOR, A. B.; GRISI, M. F. M.; TABA JÚNIOR, M. \& SOUZA, S. L. S. Depleción de células inmunocitarias durante la curación de una herida como efecto desnutrición postnatal. Int. J. Morphol., 23(1):25-32, 2005.

RESUMEN: La desnutrición postnatal está asociada a un conjunto de secuelas agudas y crónicas, y su recuperación es aún asunto controvertido. En Brasil, a pesar de estar disminuyendo la desnutrición, algunos estudios han demostrado que alrededor del $31 \%$ de los niños presentan malnutrición moderada o severa. El objetivo del presente estudio fue inducir una desnutrición precoz en ratas y observar los efectos inmediatos (desnutrición) y permanentes (depués de la recuperación) sobre las células de defensa involucradas en la cicatrización. La desnutrición fue provocada separando las crías de sus madres, por 10 horas diarias, durante el periodo de lactancia (21 días de nacidos). Como contoles fueron usadas ratas de la misma edad no sometidas a restrición láctea. Los estados de desnutrición y de recuperación fueron evaluados por el peso corporal. Las heridas fueron realizadas en la piel rasurada del dorso de los animales desnutridos, recuperados y controles, bajo anestesia con tribromoetanol. Los animales fueron sacrificados 1, 3, 7 y 14 días después de la cirugía y los tejidos de la región cicatricial fueron procesados histológicamente y examinados al microscopio óptico. Los resultados mostraron que: 1) el número de neutrófilos, linfocitos y macrófagos en la área de cicatrización, fue menor en los animales desnutridos y en recuperación que en los controles; 2) en los animales recuperados hubo una deficiencia basal en el número de linfocitos y macrófagos, lo que no ocurrió en los animales con desnutrición aguda. Estos resultados permitieron concluir que los animales sometidos a desnutrición postnatal mostraron una recuperación completa en el peso físico después del periodo de recuperación nutricional, pero que la región de cicatrización mostró menor densidad de células de defensa, sugiriendo secuelas permanentes de la desnutrición postnatal.

PALABRAS CLAVE: Desnutrición; Cicatrización; Células de defensa.

\section{REFERENCES}

Ayello, E. A.; Thomas, D. R. \& Litchford, M. A. Nutritional aspects of wound healing. Home Healthcare Nurse, 17(11):719-29, 1999.

Barret, D. E. \& Frank, D. A. The Effects of Undernutrition on Children's behavior. Gordon and Breach Sciences, New York, 1987. V. 6.

Chandra, J. K. Immunocompetence is a sensitive and functional barometer of nutritional status. Acta Paed. Scand., 374 (Suppl):129-32. 1991.

Emery, P. W. \& Sanderson, P. Effect of dietary restriction on protein synthesis and wound healing after surgery in the rat. Clinical Science, 89:383-8, 1995.

Frank. R.; Adelmann-Grill, B. C.; Herrmann, K.; Haustein, U. F.; Petri, J. B. \& Heckmann, M. Transforming Growth Factor-b Controls Cell-Matrix Interations of Microvascular Cells by Downregulation of Integrin Expression. J. Invest. Dermatol., 106(1):3641, 1996.

Gaffney, E. A modified Giemsa. Histopathology Laboratories of the Armed Forces Institute of Pathology, Washington, 1983.

Goodson, III, W. H. \& Hunt, T. K. Wound healing and the diabetic patient. Surg. Gynecol. Obstr., 149:600-8, 1979.
Keller, E. A.; Mumaro, N. I. \& Orsingher, O. A. Perinatal undernutrition reduces alpha and beta adrenergic receptor binding in adult rat brain. Science, 215(4537):1269-70, 1992.

Loots, M. A. M.; Lamme, E. M.; Zeegelaar, J.; Mekkes, J.R. Bos, J. D. \& Middelkoop, E. Differences in cellular infiltrate and extracellular matrix of chronic diabetic and venous ulcers versus acude wounds. J. Invest. Dermatol., 111(5):850-7, 1998.

Manjarrez, G. G.; Magdaleno, V. M.; Chagoya, G.; Hernández, R. J. Nutritional recovery of brain serotonin synthesis in the ontogenetically malnourished rat. Intern J. Develop. Neurosc., 14(5):641-8, 1996.

Moore, K.; Ruge, F. \& Harding, K. G. T Lymphocytes and the lack of activated macrophages in wound margen biopsies from chronic leg ulcers. Br. J. Dermatol., 137: 188-94, 1997.

Most, D.; Hoyt, J. \& Sibley, R. K. Press BHJ. Parenchymal cytokine expression precedes clinically observed ischemia in dorsal flaps in the rat. Plast. Reconstr. Surg., 98(5):856-61, 1996.

Mustoe, T. A.; Pierce, G. F.; Thomason, A.; Gramates, P.; Sporn, M. B. \& Devel, T. F. Accelerated healing of incisional wounds in rats induced by transforming growth factor-b. Science 237(4820):1333-6, 1987. 
MACARI, Z. M.; CAVENAGHI, F. M.; KOMESU, C. M.; LUNARDI, O. L.; SALA, M. A.; NOVAES JÚNIOR, A. B.; GRISIS, M. M. F.; TABA JÚNIOR, M. \& SOUZA, S. S. L.

Punch, J. \& Ivinski, A. Protein deprivation and behavior: conceptual and methodological problems. Behav. Biol.: 19(1):108-29, 1977.

Reichnhein, M. E. \& Hasselmann, M. H. Desnutrição no Brasil - Um novo perfil da criança desnutrida. A violência doméstica pode estar por trás de casos residuais de desnutrição. Jornal Folha de São Paulo. São Paulo, 18 de Maio, 5(7), 1977.

Salmon-Ehr, V.; Ramont, L.; Godau, G.; Birembaut, P.; Guenounou, M.; Bernard, P. \& Maquart, F-X. Implication of interleukin-4 in wound healing. Lab. Invest., 80(8):1337-43, 2000.

Shakir, A. Anthropometric field methods: Simplified methods. - Cap. 18 "in" Jelliffe \& Jelliffe. Nutrition and Growth vol. 2 of Human Nutrition: A Comprehensive Treatise, Plenum Press, New York and London 1979.

Tarlton, J. F.; Vickery, C. J.; Leaper, D. J. \& Bailey, A. J. Post-surgical wound progression monitored by temporal changes in the expression of matriz metalloproteinase9. Br. J. Dermatol., 137(4):506-16, 1997.

Whitby, D. J. \& Ferguson, M. W. J. Immunohistochemical localization of growth factors in fetal wound healing. Develop. Biol., 147:207-15, 1991.
Correspondence to:

Profa. Dra. Marilena Chinali Komesu

Depto. de Morfologia, Estomatologia e Fisiologia

Faculdade de Odontologia de Ribeirão Preto - USP

Via do Cafe - s/n, Campus da USP - RP

CEP: $14.040-904$

Ribeirão Preto - SP

BRASIL

$\mathcal{F a x}$ 55-16-633-0999

E-mail-mckomesu@usp.6r

Received: 14-08-2004

Accepted: 09-11-2004 